\title{
Low Grade Endometrioid Stromal Sarcoma of the Vagina
}

National Cancer Institute

\section{Source}

National Cancer Institute. Low Grade Endometrioid Stromal Sarcoma of the Vagina. NCI Thesaurus. Code C40271.

An infiltrating sarcoma that arises from the vagina. It is characterized by the presence of cells that resemble endometrial stromal cells. 